4-2008

\title{
Nociceptive Polycationic Peptides Are Chemorepellents in Tetrahymena thermophila
}

Alicia E. Schaffner

schaffna@cedarville.edu

Heather G. Kuruvilla

Cedarville University, heatherkuruvilla@cedarville.edu

Follow this and additional works at: http://digitalcommons.cedarville.edu/

science_and_mathematics_presentations

Part of the Biology Commons, and the Cell Biology Commons

\section{Recommended Citation}

Kuruvilla, H. G., Schaffner, A.E. Nociceptive Polycationic Peptides are Chemorepellents in Tetrahymena thermophila. LB 206 (LateBreaking Abstracts). Presented at Experimental Biology 2008, April 2008.

This Poster Session is brought to you for free and open access by DigitalCommons@Cedarville, a service of the Centennial Library. It has been accepted for inclusion in Science and Mathematics Faculty Presentations by an authorized administrator of

DigitalCommons@Cedarville. For more information, please contact

digitalcommons@cedarville.edu. 


\section{Nociceptive Peptides are Chemorepellents in Tetrahymena thermophila}

CEDARVILLE

Heather G. Kuruvilla and Alicia E. Schaffner

minerity

Department of Science and Mathematics, Cedarville University, Cedarville, OH 45314 USA

\section{Introduction}

Chemorepellents are compounds which cause a cell to move away from the source of the repellent, or down a concentration gradient of the compound. In ciliates such as Tetrahymena thermophila and Paramecium tetraurelia, this reorientation is accomplished by ciliary reversal, resulting in jerky or backward swimming which is known as an "avoidance reaction". This reaction characterization of ciliate bet A number of compounds are known chemorepellents in Tetrahymena thermophila, including ATP and GTP which have a negative overall charge, and polycations such as lysozyme and pituitary adenylate cyclase activating polypeptide (PACAP) which have multiple positive charges. The physiological significance of these chemorepellents is uncertain. Nucleotide triphosphates, such as ATP and GTP, have been postulated to serve as a warning signal to other cells that cellular lysis has occurred, analogous to "blood in the water" polycations such as lysozyme are thought to be similar to naturally occurring sensing the polycation gradient.

Since we have previously found that polycationic peptides such as lysozyme and PACAP are chemorepellents in Tetrahymena which appear to signal

through a G-protein tinked receptor, we decided to explore whether human nociceptive peptides would also cause Tetrahymena to exhibit avoidance through a similar mechanism. The peptides we tested. ACTH 1-24, PTH, substance $P$, and bradykinin all carry a net positive charge at a pH of 7.0 and are associated with $G$ protein linked receptos in humans. Our hypothesis was that the efficacy of the compound in terms of causing avoidance would be would all work through a single receptor, the previously characterized lysozyme/PACAP receptor (Mace et at., 2000; Hassenzaht et al., 200

\section{Materials and Methods}

Tetrahymena thermophila, strain B2086, a generous gift from T.M. Hennessey (SUNY-Buffalo) was used for all of the experiments. Cells were grown at 250 in the axenic medium of Dentler (1988), without shaking or addition of antibiotics. Two-day old cell cultures were used for all behavioral assays described below.

Chemicals and solutions. Behavioral assays were carried out in a buffer of $\mathrm{pH}$ repellents and inhibitors used were dissolved in this buffer.

Behavioral assays. Behavioral assays were carried out as previously described (Kuruvilla et al. 1997; Mace et al. 2000). Briefly, cells were washed in buffer and $300 \mu \mathrm{l}$ of cell suspension was transferred to the first well of a 3 well spot microtiter plate. Cells were then individually transferred by micropipette to the second well, which contained $300 \mu \mathrm{l}$ of buffer as a control. Cells were then transferred to a third well which contained $300 \mu \mathrm{l}$ of for signs of avoidance. Avoidance behavior was characterized by jerky, backward movements, swimming in small, tight circles, sudden reversal of swimming direction, or any deviation from the normal helical swimming pattern of Tetrahymena thermophila. Each cell was individually scored as being positive or negative for avoidance.

\section{Results}

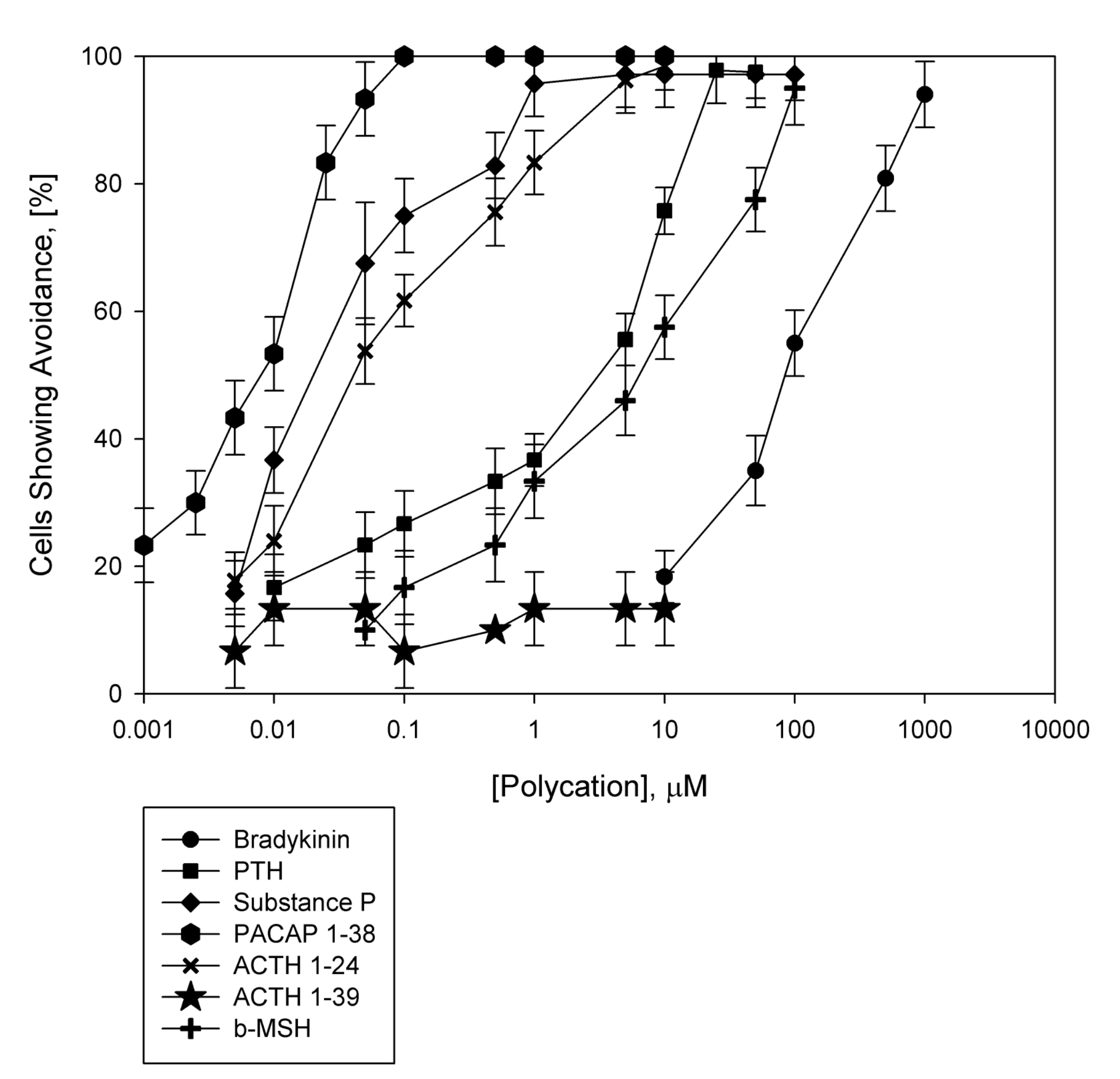

Figure 1. Nociceptive peptides are chemorepellents in Tetrahymena thermophila. Behavioral assays indicate that PACAP $1-38, A C T H 1-24$, parathyroid hormone, substance P, b-MSH, VIP, and bradykinin all elicited an avoidance response in a concentration-dependent fashion. Each trial consisted of scoring ten cells as either positive or negative for avoidance. Each data point represents the mean \pm SD of at least 6 trials.

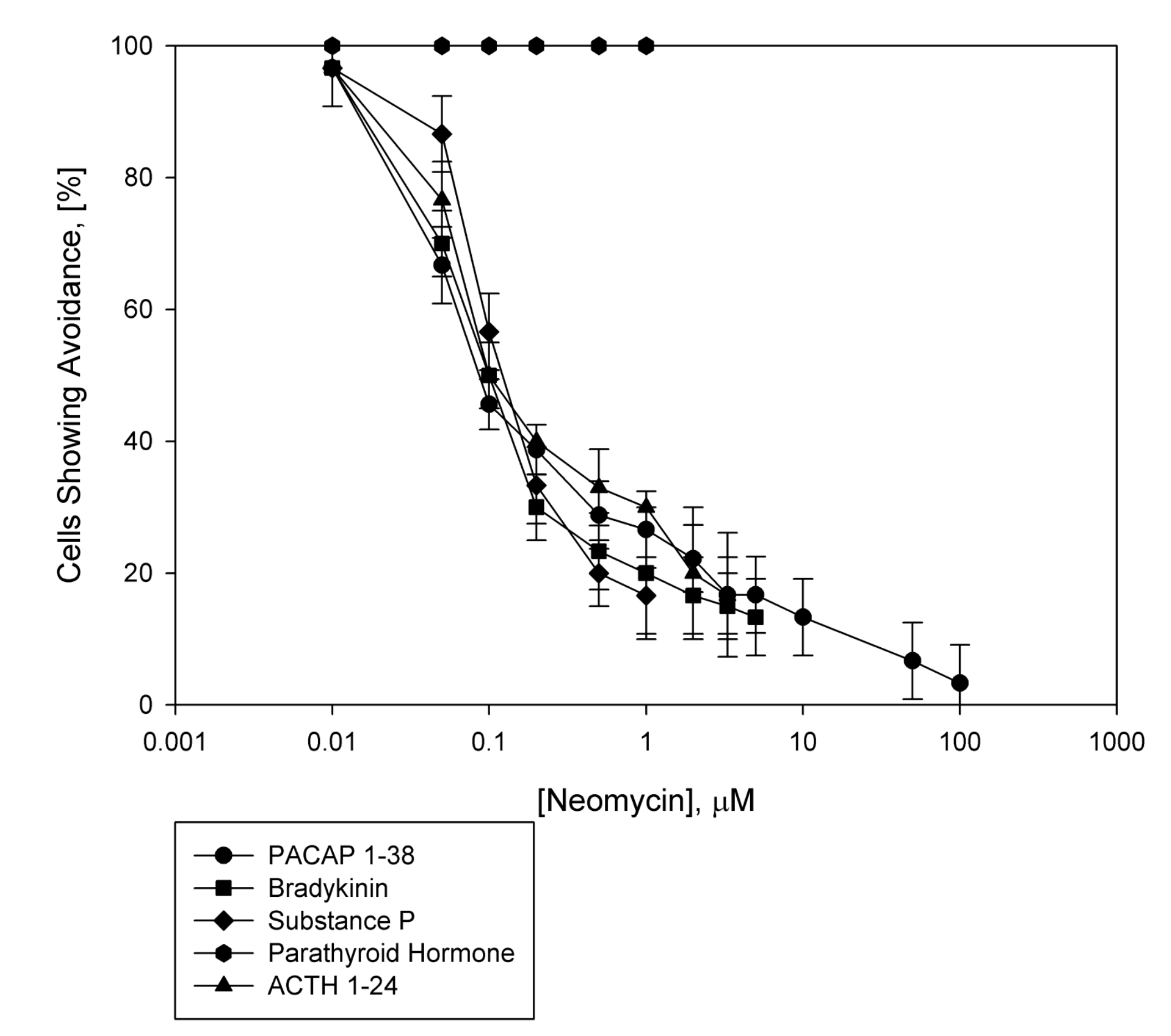

Figure 2. Neomycin sulfate inhibits avoidance to a number of polycationic peptides in Tetrahymena thermophila. Neomycin sulfate, a competitive inhibitor of lysozyme binding to its receptor (Kuruvilla et al., 1997) effectively eliminated avoidance to PACAP 1-38, bradykinin substance $P$, and ACTH 1-24 while having no affect on avoidance of PTH. The $\mathrm{IC}_{100}$ of neomycin ranged from 5-50 $\mathrm{\mu M}$, depending on the peptide tested. The $\mathrm{IC}_{5_{0}}$ of neomycin was approximately $0.1 \mu \mathrm{M}$ for PACAP $1-38$ bradykinin, and ACTH 1-24, and $5 \mu \mathrm{M}$ for substance P. Each trial consisted of scoring ten cells as either positive or negative for avoidance. Each data point represents the mean \pm SD of at least 6 trials. Previous studies (Mace et al., 2000) have shown that neomycin also inhibits avoidance to VIP. The effects of neomycin on b-MSH have not yet been determined.
Table 1: Characteristics of Polycationic Peptides. Positively charged amino acids are indicated in bold font, negatively charged amino acids are indicated in itatic font. Net charese was calculated by subtracting the negatively charyed amino acids from the positively charged amino acids. $\mathrm{EC}_{100}$ values were obtained from Figure 1 .

\begin{tabular}{|c|c|c|c|c|}
\hline Peptide & Amino Acid Sequence & $\begin{array}{l}\text { Total } \\
\text { Number } \\
\text { of Positive } \\
\text { Charges }\end{array}$ & $\begin{array}{l}\text { Net } \\
\text { Charge } \\
\text { at pH 7,0 }\end{array}$ & $\mathbf{E C}_{\mathbf{1 w h}, \mu \mathrm{M}}$ \\
\hline b-MSH & 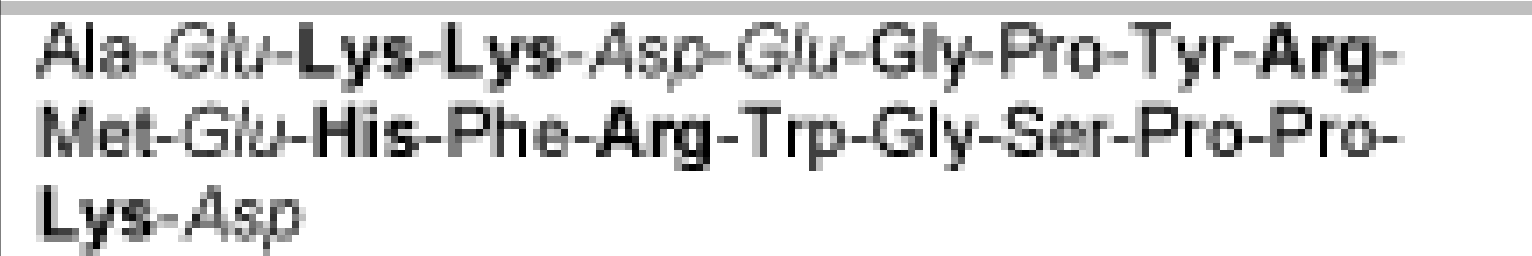 & 6 & +1 & 100 \\
\hline${ }_{39}^{\text {ACTH 1- }}$ & 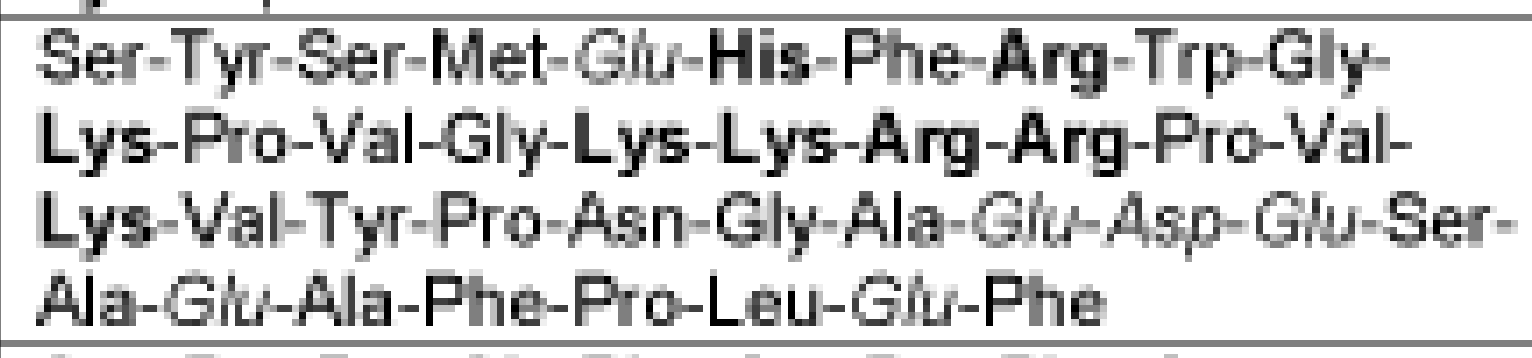 & 8 & +2 & $\begin{array}{l}\text { Not } \\
\text { determined }\end{array}$ \\
\hline Bradykinin & Arg-Pro-Pro-Gly-Phe-Ser-Pro-Phe-Arg & 2 & +2 & 1000 \\
\hline $\begin{array}{l}\text { Substance } \\
\text { P }\end{array}$ & $\begin{array}{l}\text { Arg-Pro-Lys-Pro-Gln-Gln-Phe-Phe-Gly-Leu- } \\
\text { Met-NH2 }\end{array}$ & 3 & +3 & $\mu$ \\
\hline PTH & 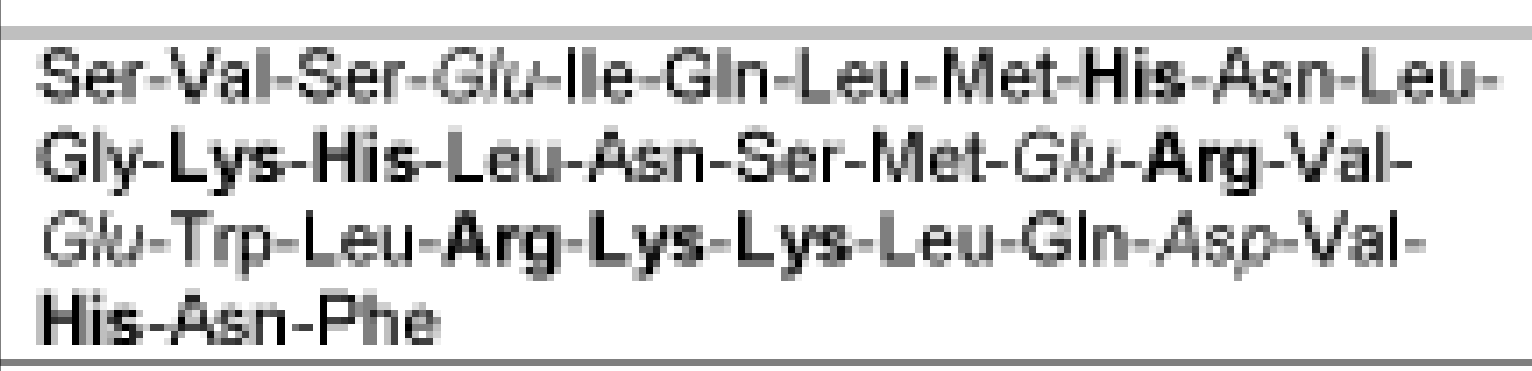 & 8 & +4 & 10 \\
\hline VIP & 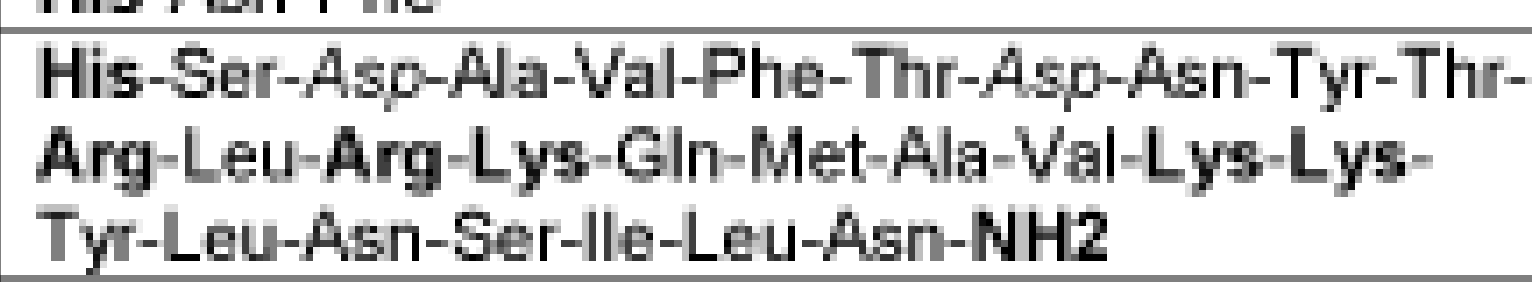 & 7 & +5 & 50 \\
\hline $\begin{array}{l}\text { ACTH 1- } \\
24\end{array}$ & $\begin{array}{l}\text { Ser-Ty-Ser-Met-Giu-His-Phe-Arg-Trp-Gily } \\
\text { Lys-ro-Val-Gly-Lys-Lys-Arg-Arg-Pro-VVal- } \\
\text { Lys-Val-Ty-Pro }\end{array}$ & 8 & +7 & 5 \\
\hline $\begin{array}{l}\text { PACAP 1- } \\
38\end{array}$ & 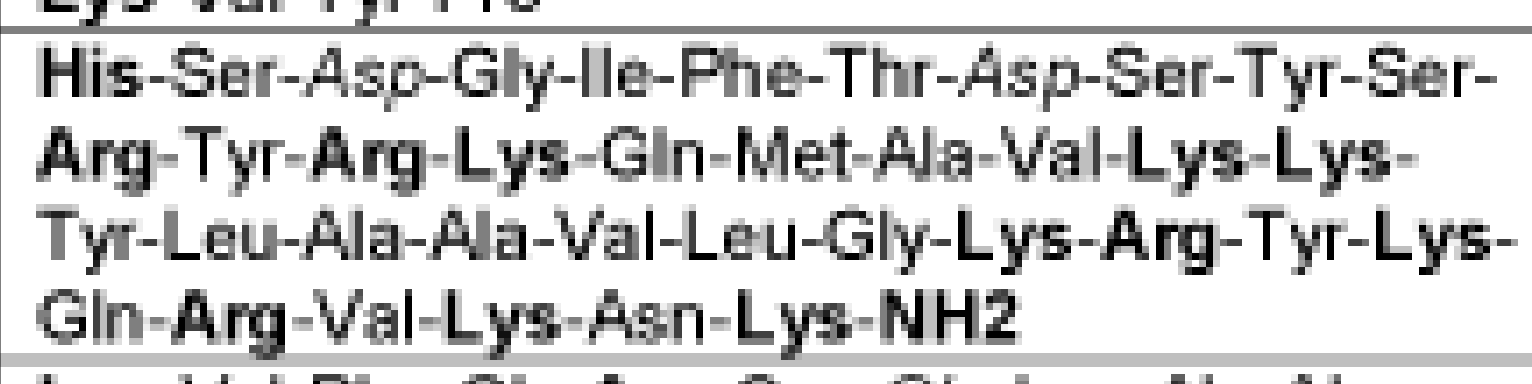 & 13 & +11 & 0.1 \\
\hline lysozyme & 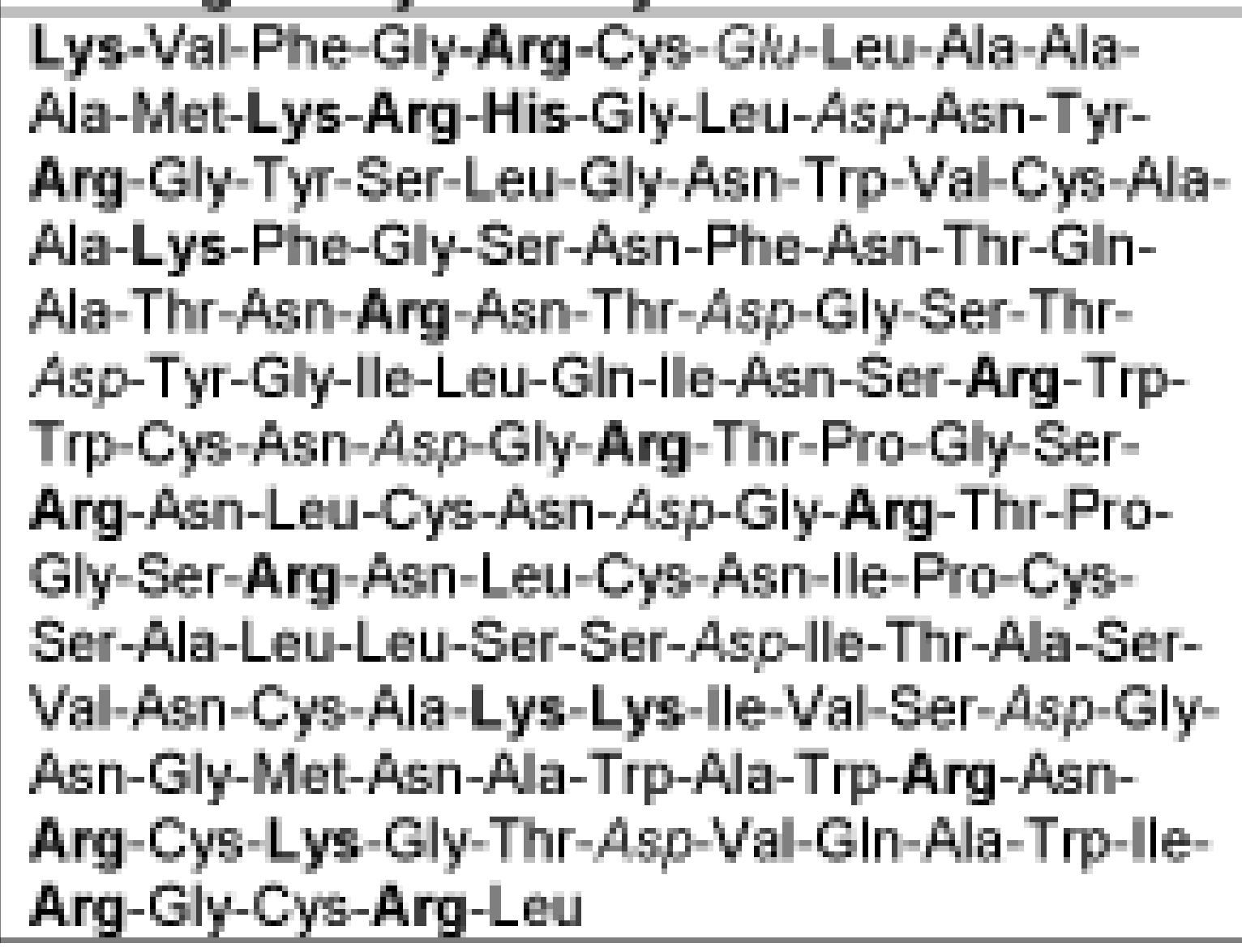 & 20 & +11 & 100 \\
\hline
\end{tabular}

\section{Conclusions:}

-Many polycationic nociceptive peptides are chemorepellents in Tetrahymena thermophila.

-In general, higher positive charge correlates with lower $\mathrm{EC}_{100}$ values. However, peptide folding and size also appear to play a role (compare lysozyme and PACAP).

- Neomycin sulfate blocks signaling of a number of these peptides, suggesting a possible shared receptor or second messenger pathway. . References:

Hassenzahl DL, Yorgey NK, Keedy MD, Price AR, Hall JA, Myzcka CC, Kuruvilla HG (2001) Chemorepellent signaling through the PACAP//ysozyme receptor is mediated through CAM Kuruvilla HG, Kim MY, Hennessey TM (1997) Chemosensory adaptation to lysozyme and GTP 44(3): 263-268 Mace SR, Dean JG, Murphy JR, Rhodes JL (2000) PACAP-38 is a chemorepellent and an
agonist for the lysozyme receptor in Tetrahymena thermophila. J Comp Physiol A 186: 39 - 